\title{
Evaluation of some sugarcane growing red, red laterite and black soils of Medak district of Telangana
}

C. Mahesh, Rajeshwar Naik Malavath, D. Balaguruvaiah and GECH Vidyasagar

Received : 08.03.2019; Revised : 01.11.2019; Accepted : 11.11 .2019

MEMBERS OF RESEARCH FORUM:

Corresponding author : C. Mahesh, Department of Soil Science and Agricultural Chemistry, College of Agriculture, Prof. Jayashankar Telangana State Agricultural University, Hyderabad (Telangana) India

Email: rajeshoct31naik@gmail.com

Co-authors :

Rajeshwar Naik Malavath, D. Balaguruvaiah and GECH

Vidyasagar, Department of Soil Science and Agricultural Chemistry, College of Agriculture, Prof. Jayashankar Telangana State Agricultural University, Hyderabad (Telangana) India

\section{Summary}

A reconnaissance soil survey was undertaken in sugarcane growing soils of Medak district of Telangana to assess the characteristics of soils, evaluate the land by identifying potentials and limitations to suggest suitable management options in the perspective of developed land use decision for effective utilization of resources. Soil samples (128 surface and 128 subsurface) were collected at a depth of $0-15 \mathrm{~cm}$ and $15-30 \mathrm{~cm}$ and analyzed for morphological, physical, physico-chemical and available major nutrient status. All the surface and subsurface soils well developed structural variation and exhibited granular to sub angular blocky structure in surface and sub angular blocky to angular blocky in subsurface horizon. The textural classes of the district are sandy loam, sandy clay loam, sandy clay to clay loam and clay. The consistence of soils varied from loose to hard, very friable to firm, non-sticky, non- plastic to very sticky, very plastic in dry, moist and wet conditions, respectively. The $\mathrm{pH}$ ranges between extremely acidic to moderately alkaline in reaction and EC was non-saline. The organic carbon content ranged from low to high in surface soils and low to medium in subsurface soils. The soils are low to medium in available $\mathrm{N}$, medium to high in $\mathrm{P}$ and $\mathrm{K}$ in surface soils. Major soil constraints include texture, erosion, slope, depth, drainage and low organic carbon, low availability of $\mathrm{N}$ and micronutrients. If the improvements could be done, there is scope that the area under marginally suitable may be converted to moderately suitable to highly suitable for the cultivation of different crops.

Key words : Sugarcane growing red, Red laterite, Black soils, Available macronutrients, Constraints, Management

How to cite this article : Mahesh, C., Malavath, Rajeshwar Naik, Balaguruvaiah, D. and Vidyasagar, GECH (2019). Evaluation of some sugarcane growing red, red laterite and black soils of Medak district of Telangana. Asian J. Soil Sci., 14 (1\&2) : 1-12 : DOI : 10.15740/HAS/AJSS/14.1and2/1-12. 